\title{
Writing the irogonomi: Sexual politics, Heian-style
}

April Sprague

University of Sydney

\begin{abstract}
Promiscuous "connoisseurs of love" (irogonomi) such as the fictional Genji and the semi-legendary Ariwara no Narihira have come to define popular perception of Heian period sexual politics; that is, their names have become shorthand for male privilege over women. In this article I will complicate established ideas regarding male promiscuity and privilege in the Heian period through an examination of Tales of Ise, Tale of Lady Ochikubo and Tale of Genji. I argue that, although women's status as linchpins in the practice of "marriage politics" rarely translated into women's individual empowerment, men's reliance on marriage politics placed restrictions on men's sexuality in ways that are rarely acknowledged by modern scholarship.
\end{abstract}

\section{Keywords}

Heian period, male sexuality, literature, irogonomi, Genji

Approximately one thousand years ago, during the flowering of Japanese culture in the Heian period (794-1185), aristocratic women composed vernacular poetry, diaries, and works of fiction that have survived the test of centuries to become staples of classical literature. Although works such as Makura no sōshi, Kagerō nikki, and the poetry of Ono no Komachi and Izumi Shikibu have been the subject of much scholarly attention, Genji monogatari (The Tale of Genji) by Murasaki Shikibu emerges as the great representative work of the period.

In this article, I call for a re-reading of male sexuality and patriarchy in mid-Heian literature. For my study, I have selected two male-authored texts, Ise monogatari (Tales of Ise) and Ochikubo monogatari (Tale of the Lady Ochikubo), and one female-authored text, Genji monogatari. ${ }^{1}$ I have identified two particular models of male sexuality present in these works: the better-known 'promiscuous' irogonomi-a 'connoisseur of love'-and the rarely acknowledged monogamous type.

First I will briefly introduce necessary background information on the Heian period. I will then examine Ise monogatari in light of the phenomenon that Mostow has

\footnotetext{
1 Mostow and Tyler (The Ise Stories: Ise Monogatari, pp. 3-4) note that Katagiri Yōichi's "three-stage" theory of composition (Narihira wrote an Ur-text prior to 880, which was expanded upon mid-tenth century, and a final addition made early eleventh century) is now widely accepted. Ochikubo monogatari is generally dated to the second half of the tenth century, and Genji monogatari is dated to the early eleventh century.
} 
dubbed 'the poem that kept her man.'2 Despite the fact that the 'hero' of Ise monogatari, Ariwara no Narihira, is seen as the archetypical irogonomi, I will demonstrate several instances of 'poem-induced' monogamy that call into question the assumption that the ideal man was always polygamous.

I will go on to examine Ochikubo monogatari. The hero Michiyori rises magically through the ranks of the bureaucracy despite his refusal to engage in marriage politics. Instead, he remains steadfastly faithful to Lady Ochikubo, a political nobody. In light of the pervasive marriage politics of the time, Ochikubo monogatari should be seen as an attempt to deny, to literally re-write, women's vital role in men's political careers.

I will conclude with Genji monogatari. It is Genji monogatari that provides the strongest rebuttal of the 'pseudo-monogamy myth', by depicting monogamy as being out of the power of even the most influential courtier to promise, no matter how much he personally loves his bride. Likewise, Genji monogatari complicates the male fantasy of irogonomi, by depicting the disasters that arise when Genji neglects to do his duty by his high-ranking wives and lovers.

In conclusion, I argue against the tendency of scholars to see masculine sexuality as monolithic, unproblematic, and always powerful. As property-owners, linchpins in the system of marriage politics, and especially as authors of prose, women were able to affect materially and ideologically male sexuality.

\section{Introduction}

Aristocratic women of the Heian period seem to have enjoyed more economic independence than their mediaeval counterparts. In Heian Japan multiple inheritance, in which the inheritance was divided between several heirs, was the norm, and women could and did inherit. ${ }^{3}$ William McCullough has suggested that inheritance of residential property in particular was often matrilineal, and even when the bequest was made by a father, daughters were often preferred over sons. ${ }^{4}$ Nevertheless, with a few rare exceptions, inheritance was the only way aristocratic women could own property. ${ }^{5}$ The primary means of wealth and property acquisition and accumulation for aristocratic men was through the 'stipendiary lands' granted to them as government officials. Despite female participation in government in the Nara period, by the Heian

\footnotetext{
Mostow, 'The Amorous Statesman and the Poetess: The Politics of Autobiography and the Kagerō Nikki'.

Tonomura, 'Women and Inheritance in Japan's Early Warrior Society', p. 592.

McCullough, 'Japanese Marriage Institutions in the Heian Period', pp. 118-24.

Wakita and Gay, 'Marriage and Property in Premodern Japan from the Perspective of Women's History', pp. 80-81.
} 
period women were almost entirely excluded from the bureaucracy and thus denied access to the main avenue for acquiring and accumulating wealth. ${ }^{6}$ Indeed, although a woman might inherit a house, she may nevertheless find herself without the means to maintain such an extensive property. Hence, no doubt, the popular literary figure of the neglected wife (or widow, or orphan) languishing away in her dilapidated house, itself masked from view by the untended, overgrown garden. On the other hand, a woman (or rather, a woman's father) was usually expected to provide economic and political support for her husband.

\section{The Bureaucracy and Rank ${ }^{7}$}

The Yōrō Code of 757 established nine major ranks for subjects (one being the highest) which were divided into senior and junior; ranks four to eight being additionally subdivided into senior upper and lower and junior upper and lower. ${ }^{8}$ Men of the court were divided into three broad groups, which were, in descending order of importance: kugyō ('senior nobles'), tenjōbito (courtiers who had been granted individual permission by the reigning emperor to enter the 'courtier's hall' of the emperor's private residence at the palace), and jige ('gentlemen of low rank'). ${ }^{9}$ Under the provisions of the Yōrō Code, a man's first rank was awarded on the basis of his father's or grandfather's rank, and whether or not his mother was the principal wife..$^{10}$ In practice, however, these rules were bent, especially for the sons of regents. ${ }^{11}$

The office of regent-usually titled sesshō for a child emperor, and kanpaku after the emperor's coming-of-age-was not covered by the Yōrō Code. ${ }^{12}$ The 'Fujiwara regency,' as the period in which members of the Fujiwara clan almost exclusively held the regent position is known, commenced with Fujiwara no Yoshifusa (804-872), who was named sesshō in $866 .{ }^{13}$ Yoshifusa set the pattern followed by successive Fujiwara regents of marrying his daughter(s) to the emperor and exerting his control as father-inlaw and maternal grandfather to the emperor. Fujiwara no Michinaga (966-1027), the most powerful of the Fujiwara regents, was at one point in the year 1018, the maternal grandfather of two emperors (Go-Ichijō and Go-Suzaku) and father-in-law of three

\footnotetext{
Fukutō and Watanabe, 'From Female Sovereign to Mother of the Nation: Women and Government in the Heian Period', p. 15; Ibid., pp. 80-81.

William McCullough and Helen Craig McCullough's translation of Eiga monogatari currently provides the definitive study of rank and office in the Heian court. See Appendix A 'Some Notes on Rank and Office' in McCullough and McCullough, A Tale of Flowering Fortunes: Annals of Japanese Aristocratic Life in the Heian Period, pp. 789-832. For the sake of consistency, I have used the McCulloughs' nomenclature for bureaucratic titles throughout, and have given preference to their English translations when individual authors have differed with them.

8 Ibid., p. 790.

10 Ibid., pp. 791, 794.

11 Ibid., p. 794.

12 Ibid., p. 795

13 McCullough, 'The Heian Court, 794-1070', p. 49.
}

9 Ibid. 
emperors (Ichijō, Sanjō, and Go-Ichijō). ${ }^{14}$ As McCullough notes, much of Michinaga's success stemmed from his fertile wives (who collectively gave him eight daughters), and his daughters' ability to bear the emperors male heirs. ${ }^{15}$ Thus, for Fujiwara courtiers of the dominant Northern branch of the clan, female offspring became very important for aspiring, and reigning, regents. ${ }^{16}$

\section{Marriage Customs}

Heian Japan was a polygynous society: men could marry multiple spouses concurrently, while, strictly speaking, women were only allowed to take one spouse at a time. The Yōrō Codes maintain a strict hierarchy between a man's (single) wife and (potentially multiple) concubines but in practice it appears that the distinction between a main wife (often identified by the appellation kita no kata) and secondary wives was not strong. ${ }^{17}$ The usual marital residency pattern for secondary wives was duolocal, in which the wife maintained her own residence and her husband 'commuted' to her. ${ }^{18}$ In the tenth century, duolocal marriage appears to have been relatively common for main wives as well, although by the eleventh century uxorilocal marriage, in which the husband resides in his wife's house, was probably the norm for principal wives. ${ }^{19}$ Given the rise in popularity of uxorilocal marriage in the latter part of the Heian period, a woman's contribution of a place of residence for her husband appears to have been a valuable one. Michinaga's grand mansion at Tsuchimikado belonged, in fact, to his wife Rinshi's family. ${ }^{20}$ It was also common for a man to rely on his wife and father-in-law for other forms of economic and political assistance; as Michinaga is quoted as saying in Eiga monogatari, 'a man's wife makes him what he is.' ${ }^{21}$ In fact, politico-economic self-interest was no doubt a large factor in deciding a man's primary spouse. Virilocal marriage, in which a wife moved into her husband's home, was rare because such an arrangement usually denoted a woman's inferior social status and inability to provide a suitable residence in which to receive her husband. Virilocal marriage is thus popular in Heian fiction, precisely because it represents a 'love' (or at least, economically disinterested) marriage of a courtier to a low-ranking or poor woman. ${ }^{22}$

Unless the groom was exceptionally young (boys underwent their comingof-age ceremony as young as age twelve, and were sometimes married at this time), a

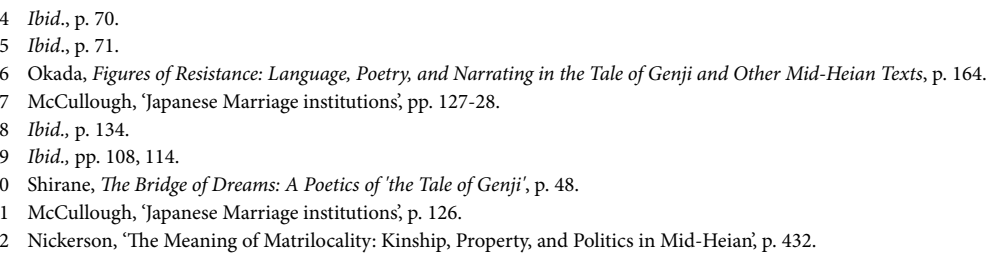


man first courted his wife-to-be. A prominent part of courtship was the exchange of letters and poetry; prospective partners were (ostensibly) judged on the quality of their calligraphy, the cleverness of their verses, and the colours and quality of paper used for the missives. The exchange of letters might last for some months before the groom visited the bride. The groom visiting three nights in a row-arriving at sunset and leaving at dawn-constituted a marriage, and on the third morning, the groom stayed on until broad daylight, when he was ritually 'discovered' by the bride's parents and partook of special 'third day' cakes. ${ }^{23}$ While this sort of marriage might seem a private affair, given the conveyances used by Heian gentleman (ox-drawn carriages and so on), the fact that courtiers had an entourage of attendants with them, the relatively small size of the capital, and the speed with which gossip travelled, the three-night ceremony actually constituted a very public affair.

\section{Ise Monogatari}

A boy and a girl...once used to play together beside a well. [...] [T] he boy had set his heart on marrying the girl, and she too was determined that she would be his wife, and refused to agree when her father tried to betroth her to someone else....[Eventually] their wishes came true and they became man and wife.

Some years later the wife's father died, leaving her without support, and the husband, tired of living with her in poverty, took to visiting a woman in the district of Takayasu in Kawachi Province. The wife saw him off with so little apparent resentment that he began to suspect her of having a lover. One day, pretending to set out for Kawachi, he hid in the shrubbery and watched her. After making up her face with meticulous care, she recited this poem, staring into space: 'Shall you be crossing / Tatsutayama / Quite alone by night?'

His heart swelled with love for her, and his visits to Kawachi ceased.

- Section 23, Tales of Is $e^{24}$

Ise monogatari is the oldest extant example of the uta monogatari 'poem tale' genre and one of the major works of literature of the Heian period. Most standard extant versions consist of 209 poems organized into 125 discrete narrative sections. Occasionally characters are identified by name, but for the most part they remain anonymous, referred to as simply otoko 'man' or onna 'woman'. According to certain interpretations,

23 McCullough and McCullough, op. cit., p. 297, n. 158. Cited in ibid., p. 439.

24 McCullough, Tales of Ise: Lyrical Episodes from Tenth-Century Japan, pp. 87-89. 
the nameless otoko of the various tales are said to be one and the same person, the famous poet Ariwara no Narihira (825-880). (In fact, Narihira is only explicitly named once in the entire tale). ${ }^{25}$ Nevertheless, references in Genji monogatari and Sagoromo monogatari (c. 1100) to Ise under the alternative titles Zaigo ga monogatari and Zaigo chüjō no nikki-clear references to Narihira, the 'fifth Ariwara son' (zaigo) who occupied the post of Middle Captain $(c h \bar{u} j \bar{o})$ - suggest that by the late Heian period Narihira was accepted as the protagonist of the tales, and that the work was regarded as his nonfictional diary. ${ }^{26}$ Combined with the fact that many, in fact most, of the tales concern love affairs, it is not unreasonable to assume that Narihira's current reputation as a great irogonomi was already well established by mid-Heian.

Many scholars see the semi-fictional Narihira of Ise monogatari as the inspiration for the great gallant of Heian literature, 'Shining' Genji. ${ }^{27}$ Nakamura Shin'ichirō identifies Narihira as a 'representative' (daihyōsha) of irogonomi and a 'Japanese aesthetic Don Juan' ${ }^{28}$ It is precisely this model of male sexuality, the irogonomi, that has come to dominate contemporary perception of the Heian period.

Scholars of Ise monogatari have generally read the promiscuity of Narihira as an expression of his cultural refinement. That is, an irogonomi pursues sexual relations with many women not out of politico-economic self-interest, but because he appreciates the 'pathos' (mono no aware) inherent in elegant love affairs. ${ }^{29}$ Or, as Haruo Shirane additionally notes, 'amorous heroes' such as the semi-fictional Narihira seek love as a reaction to the marriage system of the day:

In an age when court marriage was usually an arrangement between families, a contract in which the opinions of the bride and groom were of little consequence, it comes as no surprise that the hero of the Ise monogatari should discover love outside the institution of marriage. The amorous hero is not simply a libertine or rake; he pursues a certain woman because he is genuinely interested in love, beauty, and poetic sensitivity-so often ignored in marriage. ${ }^{30}$

Additionally, Nakamura states that the 'form of love' (ai no katachi) known as irogonomi is 'the ideal of love produced by the Heian period, in which the civilisation of our country [Japan] attained the highest sensuous refinement. ${ }^{31}$ However, I wish

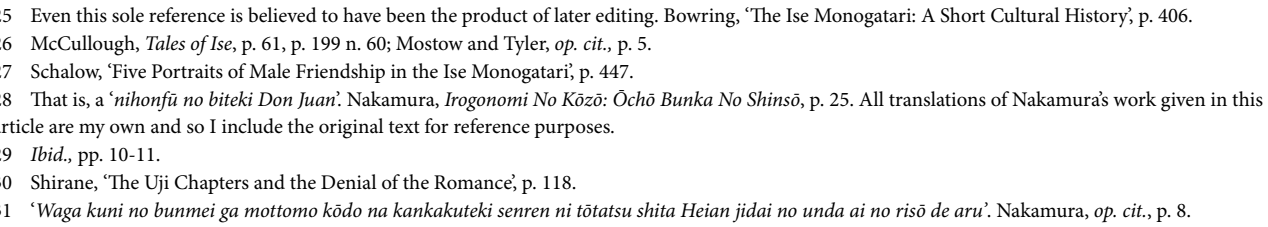


to complicate Nakamura's assertions that the promiscuous irogonomi represented the ultimate ideal of masculine sexuality in the Heian period. A close reading of the literature suggests another valid model of sexuality in which monogamous behaviour becomes the site of expression of refined aesthetic sensibilities. In order to explain this latter model, I would like to introduce the literary trope that Joshua Mostow has labelled 'the poem that kept her man. ${ }^{32}$ The conceit that a woman could retain or renew a man's romantic affections with a single, well-penned poem bears further investigation. By examining the deployment of 'the poem that kept her man', I also hope to demonstrate the way in which monogamous behaviour was also a site for the expression of refined aesthetic sensibility, for in reaffirming his love for the poetess, a man concedes her superior aesthetic sensibilities; to be unmoved by her poem is to be boorish and uncultured.

In Ise monogatari, we see examples of male infidelity that are portrayed as a rational, self-serving choice. Section 23, quoted at the beginning of this chapter, describes a situation in which a man and woman marry despite her father's objections, but when her father dies and deprives her of economic support, her husband starts visiting another woman. (I would like to note that even if we follow the interpretation that Narihira is the protagonist of the tales, there are some otoko that are clearly unidentifiable with him, such as the man, a son of an itinerant peddler, in Section 23). ${ }^{33}$ In this case, it is not the man's desire to be seen as a worldly, cultured irogonomi that causes his 'infidelity' but the fact that he is no longer willing to live in poverty as his wife can no longer financially keep him. As I have previously mentioned, a husband often relied on his wife and her family for economic support; if a woman's father died, she often inherited the house, but generally did not have access to an income. However, one night when he is about to visit his lover, he spies his wife, who chants the poem: 'Shall you be crossing Tatsutayama quite alone by night?' His desire for his lover instantly vanishes, and he rushes faithfully back to his wife's side. If the male prerogative to have sexual relations with as many women as he pleased were so ingrained and so unproblematic then one would assume that there should be no reason for him to give up his lover in favour of his wife. Likewise, if the mark of a cultured man was his relationships with multiple women, as Nakamura argues, then the otoko of Section 23 should not give up his other lover.

There are numerous other examples of the phenomenon of 'the poem that kept her man' in Ise monogatari. Consider Section 22, in which an estranged couple have begun to exchange letters again. The man comes to visit that very night, and recites the poem: 'Would I be satisfied / If I might count / A thousand autumn nights as one / And sleep with you / Eight thousand nights?. When she replies 'Were we to 
make / A thousand autumn nights / Into one, / There would still be things to say / At cockcrow', the text notes that, because of the refinement she displays with this poem, the man thereafter visited her 'more faithfully than ever.' ${ }^{34}$ Likewise, in Section 123, a man composes a poem to a woman suggesting that he will 'leave the house / Where I have dwelt / These years' (presumably it is a matrilocal marriage) she replies, 'If it be a wild field / Then I shall be a quail / Calling plaintively- / And surely you will at least / Come briefly for a hunt', the man is 'deeply moved' by her poem and 'no longer felt inclined to leave.. ${ }^{35}$

Perhaps one of the most remarkable points of Section 23 is the attitude towards marriage that it portrays. It has been pointed out that for most of history, for most cultures, marriage has functioned as a contract between families (or a contract between a groom and his father-in-law) that has had much to do with economic and political expediency and little to do with love or emotional attachment. And yet the episode in Section 23 portrays a remarkably 'modern' sensibility. The woman 'loves' the man and refuses to marry the person her father has chosen for her. ${ }^{36}$ Their marriage is decided upon between themselves, without familial interference. But here is the rub: when the man starts to neglect his wife and visit the lady at Kawachi it is because his wife can no longer financially keep him, and presumably not because of any change in his feelings towards her personally. Of course, the episode does not enlighten us as to what drew the man to the woman in the first place, only that he was 'determined to have her'; ${ }^{37}$ it may well have been that the man's initial interest in the woman was mercenary enough. And yet, the man rushes back to his wife's side when she intones the 'Tatsutayama' poem. Presumably, his wife's economic situation cannot have changed for the better; and yet he takes her over the Kawachi lady, who would seem to be the more practical choice, for presumably the Kawachi lady can support him. Should we call the man's renewed fidelity to his wife 'love'? His fidelity is almost definitely not inspired by economic or political self-interest.

Instances such as these have been largely ignored by scholarship. Nakamura insists that men who were loyal to just one woman were considered to be ill, or emotionally immature. ${ }^{38}$ However, I would suggest that, rather than reading the actions of the man in Section 23 of Ise monogatari as merely the result of emotional immaturity, in reaffirming his loyalty to his partner, this man was in fact acting in accordance with contemporary aesthetic sensibilities.

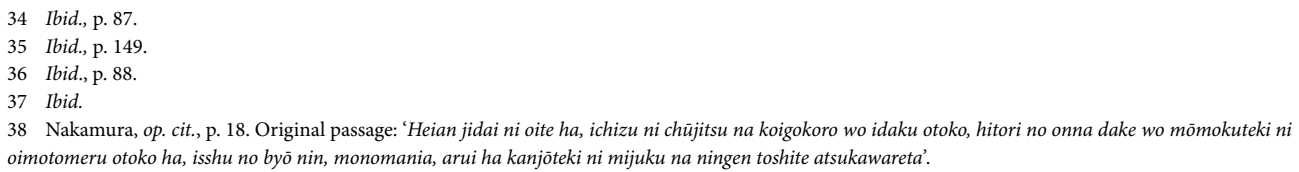


Finally, I would like to make a closing remark on politics and rank. The fictional Narihira, as the assumed protagonist of most of the tales of Ise monogatari, for the most part operates in a political vacuum. Excepting a few episodes in which the fictional Narihira has an affair with a woman who is intended as an imperial consort, resulting in Narihira's exile, Narihira's numerous affairs are untroubled by issues of politics or rank. The real-life Narihira himself never rose past junior fourth rank upper, and never occupied any of the prestigious posts of the bureaucracy, living instead as a fashionable gentleman of leisure. ${ }^{39}$ Likewise, the anonymous, rank-less men and women of Ise monogatari that I have used as examples of fidelity conduct their love affairs untouched by issues such as bureaucratic promotion. My examination of Genji monogatari later in the article will show the problems that occur when really high ranking nobles follow their heart too much. For even though Narihira may have been the model for Genji, I will argue that Genji's actions as an irogonomi, as well as his attempts at fidelity, are ultimately restricted, not enabled, by his great rank.

\section{Ochikubo Monogatari}

'How unreasonable you are!' exclaimed [Michiyori's] foster-mother. 'The Minister [of the Left] has been making all the preparations in great expectation.... How can you reject the proposal which such a noble lord urges on you?... It is the custom nowadays to marry someone whose parents can help one with their favour. ... One cannot be permanently happy unless one has the loving care not only of a wife but also of her parents.'

[Michiyori] reddened at this speech. 'Perhaps it is because my ideas are oldfashioned that I do not like those things which are considered polite and upto-date. I do not wish for success. I do not want the favour of my wife's parents. I shall not give up the Lady [Ochikubo] of Nijō...'

- Tale of the Lady Ochikubo ${ }^{40}$

In this section on Ochikubo monogatari, I will expand on a concept presented in the previous section on the Ise monogatari: that of 'the poem that kept her man.' Donald Keene describes Michiyori, the male protagonist of the tale, as 'a model Heian husband and, that great rarity, a confirmed monogamist. ${ }^{41}$ Michiyori certainly does make a striking contrast with the semi-fictional Narihira of Ise monogatari with his countless lovers. However, as I will argue, Michiyori's devotion to his wife, Lady Ochikubo,

\footnotetext{
McCullough, Tales of Ise, p. 42.

40 Whitehouse and Yanagisawa, The Tale of the Lady Ochikubo: Ochikubo Monogatari, p. 151.

41 Keene, Seeds in the Heart: Japanese Literature from Earliest Times to the Late Sixteenth Century, p. 448.
} 
should not be considered without literary precedent. As I argued in the context of Ise monogatari, if an estranged wife or a lover in a precarious position sent her man a brilliantly composed poem, he should properly respond with renewed (if not exclusive) attention to her. Michiyori's absolute commitment to Ochikubo should be understood in light of this phenomenon, and as an extension of it; Ochikubo is a good poet, and also beautiful, sweet-tempered, and a skilled seamstress, and in committing himself to Ochikubo alone, Michiyori is acting in accordance with existing sensibilities.

And yet if we consider the practicality of Michiyori's behaviour in light of his rank, his fidelity to Ochikubo alone and his staunch refusal to marry to his political advantage is not only remarkable, it is impossible. If we examine Michiyori's nonfictional politically successful contemporaries, such as Fujiwara no Kaneie (929-990), and his son, Fujiwara no Michinaga, we find that their political success was irrevocably tied to marriage politics. This introduces my argument for this section: that Michiyori's avoidance of polygyny, and marriage politics in general, should be understood as an attempt to deny, to literally rewrite, women's importance to politics. Ambitious courtiers depended, to a large extent, on their multiple wives for access to powerful father-inlaws, for daughters to present to the emperor and princes, and to a lesser extent for access to cultural prestige. In creating a main character who rises magically through the bureaucracy to the highest rank of Chancellor (daijo daijin) by age forty, with only the influence of his father and the favour of the emperor, the author of Ochikubo monogatari tries to refute the central role of women in politics. For in reality, political marriage was not something upwardly-aspiring courtiers could avoid; monogamous marriage for love was a luxury that most courtiers could not afford.

Because the tale is not widely studied, and because the storyline of Ochikubo monogatari is central to my analysis, I will briefly give a summary of the plot here. Ochikubo monogatari is the story of Lady Ochikubo who is so nicknamed after the 'lower room' apart from the rest of the house in which she is forced to live by her stepmother. After the death of Lady Ochikubo's mother-a second-generation princess-and having no maternal relatives to look after her, she moves into the house of her father, the hen-pecked Minamoto Middle Counsellor, and is forced to make all of the fine clothes for the extended family whilst she lives in poverty herself. Michiyori, a low-ranking but apparently influential courtier and favourite of the emperor, begins secretly courting Ochikubo and eventually whisks her away to install her in his mansion. ${ }^{42}$ Michiyori rises rapidly through the ranks at court, and never takes any wife but Ochikubo, who gives him many children. The story ends with

42 Thus, it is a virilocal/neolocal marriage. As mentioned previously, marriages of this type, although a staple of fiction, had little precedent in reality. It is perhaps significant that the couple eventually move to a mansion which Ochikubo inherited from her mother (who inherited it from her father, an imperial prince). Thus, in a way, the love match between Ochikubo and Michiyori is rendered a little less transgressive. 
Michiyori being appointed Chancellor (daijō daijin), the highest bureaucratic office in the realm, and Lady Ochikubo's daughter is appointed Empress (kisaki).

\section{'The Poem That Kept Her Man'}

Let us examine Michiyori and Ochikubo's relationship in light of the literary trope presented in the last chapter, 'the poem that kept her man.' Margaret Childs is one of the few scholars publishing in English to treat with Ochikubo monogatari, albeit only in passing, in her pioneering work on the nature of love in the Heian period. ${ }^{43}$ Childs argues that Lady Ochikubo's main attraction lies in her pitiable situation as a virtual slave to her 'wicked' step mother, and that her beauty and refinement are only secondary attractions, albeit important ones. ${ }^{44}$ I agree that it is Ochikubo's sad plight that initially draws Michiyori to her, as evinced by Michiyori's reaction when his fosterbrother first informs him of the Lady's existence: 'How pitiful! What she must feel! And she is the daughter of an Imperial Princess too!? ${ }^{45}$ However, it is Ochikubo's poetic skill that secures Michiyori's affections. Consider the episode in which Ochikubo and Michiyori have spent their first night together. Dawn arrives, and it is time for him to leave. Michiyori recites a poem about the rooster crowing, and asks to hear Ochikubo's reply, because otherwise '[he] cannot feel that [they] are lovers. ${ }^{46}$ Ochikubo responds cleverly, reusing the imagery of Michiyori's poem. Michiyori reappraises his opinion of her, and the text notes that 'her voice and reply were charming, and though [Michiyori] had been thinking about her only casually, he now became truly smitten. ${ }^{47}$ That is, the text leads us to believe that before Michiyori heard Ochikubo's reply, he was not serious about her; but now he is completely in earnest with his affections.

\section{Politics and Marriage}

Let us examine Michiyori's political career in the world of Ochikubo monogatari. Michiyori begins the tale as a Lesser Captain of the Left Bodyguards (sakon-e no shōshō). At the start of the second book he is promoted to Middle Captain and additionally bestowed junior third rank, a special honour. Even though the third rank entitled Michiyori to be considered a senior noble (kugyō) he is by no means at the top of the court hierarchy. And yet, he is described in the text as 'the first man nowadays[,] [e] ven the [Chancellor],' nominally the most powerful bureaucrat in the realm, 'dare not

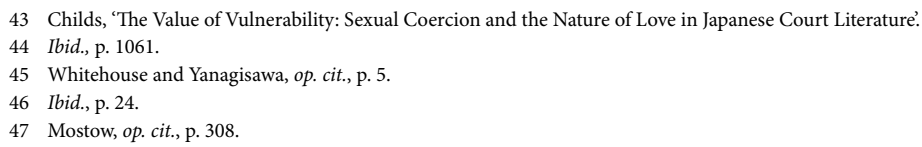


make a sound in his presence. ${ }^{48}$ Michiyori is next promoted, over the heads of others, to Middle Counsellor (chünagon) and Director of the Left Gate Guards (saemon no kami) concurrently. Michiyori, and to a lesser extent his father, are portrayed as being able to engineer office appointments however they choose. By the time Michiyori has become a Middle Counsellor it is only Michiyori's relatives that are being promoted. When Michiyori's father, the Minister of the Left, tires of the duties of his concurrent post of Major Captain of the Left (sadaishō), he simply resigns the position to his son Michiyori (who by this time is a Major Counsellor dainagon), without consulting anyone in the matter. ${ }^{49}$ In turn, Michiyori resigns the post of Major Counsellor to his father-in-law, Lady Ochikubo's father, after consulting with only his own father, who approves the decision by himself. ${ }^{50}$

But how did Michiyori become so powerful? The answer that the text gives us is that he is both the favourite son (and, luckily for him, the only politically ambitious son) of a very powerful courtier, and the favourite of the emperor. However, in reality, paternal influence could only extend so far. It was through marrying one's daughters to the emperor that one secured one's position at the top of the bureaucracy. Many scholars have pointed out that women were, for the most part, political pawns. It is true that, even though women formed the linchpin of the marriage politics system, this rarely translated into women's individual empowerment. However, this does not change the fact of men's reliance on their sisters, wives, and daughters to play the game of marriage politics. As mentioned above, it was through strategic marriage that the Fujiwara hegemony at court was established and successfully sustained. McCullough notes that 'in many cases a man's official and economic position seems to have been determined more by his father-in-law than by his father.. ${ }^{51}$ In fact, Michinaga's early political successes owe a great deal to the political connections and wealth of the family of his principal wife, Minamoto no Rinshi. ${ }^{52}$ Later, Michinaga's appointment to Minister of the Right over the head of his rival and nephew, Fujiwara no Korechika, has been attributed to his sister Senshi's intervention with the reigning emperor, Ichijō, her son. ${ }^{53}$ Even a man like Fujiwara no Kaneie, who never married very highly, married widely and placed his daughters in the 'imperial harem. ${ }^{54}$ Thus, it would seem that, even for a figure like Michinaga, a son of Kaneie who had himself occupied the exalted post of regent, marriage politics was the key to his political success.

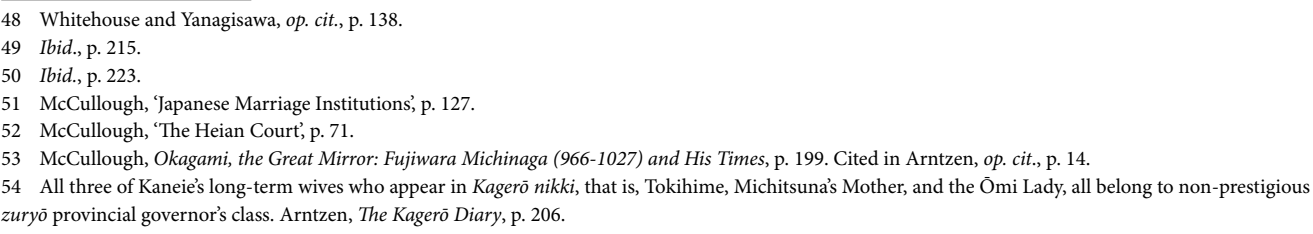


On the other hand, when we consider Michiyori, not only does he remain faithful to Lady Ochikubo, and Ochikubo alone, he flatly refuses offers of marriage from powerful courtiers. Consider the passage from Ochikubo monogatari quoted at the beginning of this chapter. The Minister of the Left, nominally the second most powerful commoner in the realm, offers Michiyori-using Michiyori's foster-mother as an intermediary - the hand of his daughter in marriage, with the strong hint that, if he accepts, Michiyori 'will be promoted to very high rank in the near future.55 Michiyori first refuses his foster-mother's match-making politely, telling her to convey to the Minister that 'I am living with one I love'. ${ }^{56}$ When his foster-mother persists in her efforts to marry him off, Michiyori responds with the impassioned speech quoted above: that he cares nothing for success or political connections, he only wants Lady Ochikubo. Michiyori's declaration is even more remarkable given that the Minister of the Left had sent word that he did not object if Michiyori wished to continue to visit the Lady Ochikubo even after his marriage to his own daughter. ${ }^{57}$

Joshua Mostow has labelled male-authored monogatari, of which Ochikubo monogatari is just one, 'patriarchal indoctrination. ${ }^{58}$ (Authorship of Ochikubo monogatari has traditionally been attributed to Minamoto no Shitagō (911-983), a scholar and one of the 'Thirty Six Poetry Immortals', however, there is no definitive evidence to support this, or any other authorship claims. ${ }^{59}$ Commentators do seem to agree that the author was a man). Ochikubo monogatari certainly is very didactic in style, with its emphasis on the importance of filial piety and female docility. However, to dismiss Ochikubo as merely an attempt to keep or put women 'in their place' is to miss out on an important dimension of the work. If the sole purpose of monogatari was indoctrination, then one might assume that it would be more profitable to inure female readers to polygyny, as opposed to promising monogamy. Furthermore, there are a number of telling passages from Ochikubo monogatari that suggest the ways in which polygyny could be problematic for men. Michiyori's mother counsels him against taking more than one wife: 'To keep many ladies is to suffer many troubles. And it is bad for your health. ${ }^{60}$ Likewise, when Michiyori overhears that the handsome Katano no Shōshō has taken an interest in Ochikubo, Michiyori jealously rants about how the Shōshō's letters are so 'effective' that '[e]very woman in the Capital allows herself to be led astray by Katano no Shōshö. ${ }^{61}$ Michiyori mentions that, because of the Shōshōs numerous affairs with married women and imperial consorts, he is never promoted. Presumably the Shōshō

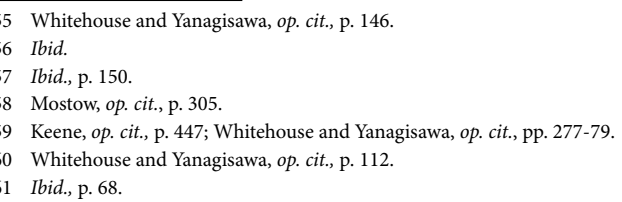


makes too many enemies in high places. And yet it seems peculiar that Katano no Shōshō, the character who most resembles the legendary Ariwara no Narihira, and who pre-empts the great lover Genji, is so roundly despised by the hero of Ochikubo monogatari. It is an acknowledgement of the threat that promiscuous men posed to other men.

The motif of faithful husband is not unique to Ochikubo monogatari. It is reworked in the great Heian prose work, Genji monogatari, in the relationship between Genji and Murasaki. Of course, Genji is not monogamous (especially not in the early chapters) but he comes to lavish most of his time and attention on Murasaki, even though her status is below his. Significantly, however, there is no happy ending for Genji and Murasaki.

\section{Genji Monogatari}

In this section I will argue that Genji, the eponymous hero of Genji monogatari should be read as an example of the inherent conflict between politics, high rank, and the practice of irogonomi. There are strong suggestions that Murasaki Shikibu at least partly modelled Genji on the figure of Narihira from Ise monogatari: both characters 'transgress' with an imperial consort, and both go into regional exile. ${ }^{62}$ However, in his devotion to semi-orphaned and politically impotent Murasaki, I would argue that Genji also closely resembles Michiyori from Ochikubo monogatari. But as I will go on to demonstrate, Genji must contend with politics in a way that Narihira and Michiyori do not, and Genji's actions bring consequences, and carry restraints, that we do not see in Ochikubo monogatari or Ise monogatari.

In Genji, Murasaki Shikibu seems to have created a perfect Heian courtier. Genji is remarkably beautiful; his robes and the perfume he uses, his poetic mastery, his calligraphy-basically, his personal comportment and mastery of high culture-set him apart from all other men. On the other hand, Genji's amorousness also brings tragic consequences, admittedly less for himself than for the women around him.

Murasaki Shikibu's unwillingness, or perhaps inability, to directly 'punish' Genji for his transgressions against the female characters may be seen as proof positive of the iron grip of the Heian patriarchy. And yet, in reusing such figures as the irogonomi, Murasaki Shikibu subtly manipulated the dual glowing andro-centric ideals of 'great

62 Bowring, op. cit., p. 419. Richard Bowring goes so far as to state that the presence of Ise monogatari in Genji monogatari is 'so all-pervasive that it may seem stretching a point to isolate specific instances'. 
lover' and 'faithful husband.' If the former-a 'Narihira-style' irogonomi-can be said to represent male fantasy (freedom from loveless political marriage) and the latter is both male fantasy and 'patriarchal indoctrination' (if you're docile, hard-working, and cultured, then your husband will be faithful to you alone) then Murasaki Shikibu puts the lie to both. Through Genji, Murasaki Shikibu denies both the carefree promiscuity of the irogonomi and the promise of fidelity from high-ranking husbands offered up by Ochikubo monogatari.

When we compare Genji and the heroes of Ise monogatari and Ochikubo monogatari, it soon becomes clear that, though Genji's character is borrowed from both, he is no Narihira or Michiyori. Narihira conducts most of his love affairs in the countryside, or at least, in a context unconcerned with politics and the machinations of the court. Michiyori and his romance with Ochikubo is likewise untroubled by politics: Michiyori and his father are simply so influential that politically-advantageous marriage is a non-issue, and presumably Michiyori need not worry about offending the Minister of the Left by refusing to marry his daughter. Genji is in a different situation entirely. The emperor's son by the orphaned, low-ranking Kiritsubo Intimate, Genji is made a commoner despite his father's preference for Genji over his other son by the powerfullybacked Kokiden Consort. In Ochikubo monogatari the emperor's favour is enough to raise Michiyori above all the other courtiers, even those who are technically by far his senior. However, in Genji monogatari the emperor's love is nowhere near enough to protect his favourite son, just as the emperor's love was not enough to protect Genji's mother from the deadly jealousies of her rivals. Echoing the marriage that Michiyori never made, after Genji's coming-of-age ceremony the emperor marries the young Genji to Aoi, the daughter of the Minister of the Left, and thus the Minister of the Left, not the emperor, becomes Genji's primary political supporter.

As Royall Tyler has argued extensively, rank is an important and allencompassing theme in Genji monogatari. ${ }^{63}$ Although aristocratic men were free to make non-binding sexual advances towards women of a lower rank than themselves, excessive devotion to such lower-class women upset the social order, such as in the case of Genji's father's ill-fated love for the Kiritsubo Intimate and the scandal it created at court. ${ }^{64}$ Although it appears that a high-ranking man was never seriously expected to be monogamous, if he did keep more than one woman then he owed the bulk of his time and devotion towards a woman of equal rank to him, and a man who married above his rank was expected to be exceptionally considerate of such a wife. ${ }^{65}$

63 Tyler, 'Marriage, Rank and Rape in the Tale of Genji'.

64 Ibid., para. 12.

65 Ibid., para. 13. 
Genji himself becomes involved with a number of very highly ranked women; here, I shall limit the discussion to the three cases of Aoi, Rokujo, and the Third Princess. $\mathrm{He}$ also becomes entangled with women who, although of nominally well-to-do birth, have lost their place in the world, such as the ladies Yügao and Murasaki. That he is involved with such 'lowly' women is not the issue; the issue is that, having involved himself with women of high birth, Genji neglects them for his lower-born lovers.

Genji's politically expedient and loveless marriage to Aoi is ever-present against the foreground of Genji's other liaisons. It is not that Aoi is lacking in her upbringing, or betrays any faults in taste, that keeps Genji away. For, as he remarks:

The look of [Aoi's residence] and the manner of the lady there [Aoi] were admirably distinguished, for neither could be faulted in any way, and it seemed to Genji that she should be the ideal wife singled out as a treasure by his friends the evening before, but in fact he found such perfection too oppressive and intimidating for comfort. ${ }^{66}$

It is Aoi's extreme pride 'at being the only daughter not just of any Minister but of the greatest of them all, and of no less than a Princess' that leads her to be severe upon Genji's shortcomings as a husband, 'while [Genji] on his side kept wondering why he must defer to [Aoi] so and keep trying to bring her around. ${ }^{67}$ In light of her rank, Aoi should command all of Genji's attentions, but she does not, for Genji rarely visits.

Although Genji is reluctantly but definitively married to Aoi, he begins to conduct an affair with the graceful Rokujō Haven. However, as Royall Tyler points out, the Rokujō Haven - the daughter of a Minister of State (daijin) and widow of the deceased crown prince-is not in a position to be treated lightly, and her exalted station demands that Genji, having consummated his relationship with her, publicly recognize her by marrying her. ${ }^{68}$ Not only does he fail to do this, but having finally won her over after a long period of her keeping her distance, he often fails to visit at all.

If Genji considers Aoi and Rokujō as burdensome because of the duty towards them that their high rank demands, then the lady Yügao becomes a prime target for romance because, although not as refined as those two great ladies, as an orphan and apparently of low rank, Yūgao cannot practically make demands of Genji. Charo D'Etcheverry terms such romances between high-ranking courtiers and women like

66 Tyler, The Tale of Genji, p. 35

67 Ibid., p. 140.

68 Tyler, 'Marriage, Rank and Rape', para. 16. 
Yūgao 'mid-ranks romance.69 D'Etcheverry argues that Murasaki Shikibu constructs mid-ranks romances as a male fantasy, as such relationships offer a temporary reprieve from loveless political marriages. ${ }^{70}$ That Genji should voluntarily spend his time visiting the lowly Yūgao instead of herself angers Rokujō. While ordinarily there is little that a woman in Rokujō's position could do (despite her high rank, she has no close male relative living to 'protect' her), in the fictional world of Genji monogatari Rokujō has unconscious recourse to spirit possession in an attempt to right the situation. And, unwittingly, it is Rokujōs living spirit (ikisudama) that kills her rival, Yūgao, thus denying the ease and privilege of Genji's 'mid-ranks romance'.

Following Yūgao's death (which Genji does not yet know was caused by Lady Rokujō), when Genjis father prophetically warns him to treat Rokujō with more respect, there is an incident at the Kamo Festival, which leads to Aoi's attendants humiliating Rokujō. Genji's public reverence for his wife at the festival, compounded by his neglect of and refusal to acknowledge Rokujō, exacerbates Rokujō’s humiliation. In unconscious retaliation, Rokujōs living spirit once more strikes out, and possesses and kills Aoi. Even with the deaths of Yūgao and Aoi, Rokujōss two main rivals, Genji fails to honour Rokujō in accordance with her station because of his disgust with her involvement in Aoi's death.

Later in the tale, Genji goes on to meet and marry the love of his life, Murasaki. After Genji has been married to Murasaki for around fifteen years, Genji is offered, and accepts, the hand of the Third Princess, favourite daughter of retired Emperor Suzaku. Even though Genji loves Murasaki, whom he has raised himself from childhood to be his ideal wife, in the eyes of the world she does not have the status to match his, as although she is the daughter of a prince, her mother died early and her step-mother prevented her father from fully recognising her. Tyler has called Genji's marriage to the Third Princess a 'thirst for heightened prestige,' for the Third Princess' status can add to Genji's own. ${ }^{11}$ In a way, the Third Princess is a trophy wife, for Genji does not care for her personally and laments her youth and lack of cultured polish. And yet, because of her lofty rank, higher than that of Aoi and Rokujō both, Genji is forced to spend time with her, because to do otherwise would invite public censure.

However, when Murasaki falls ill (later discovered to be caused by the nowdeceased Rokujō's ghost) Genji cannot bring himself to neglect her, and spends all his time by her side, completely ignoring the Third Princess. This is a fatal mistake, as while he is tending Murasaki, a young courtier slips in and seduces the Third Princess, and she

\footnotetext{
D'Etcheverry, 'Out of the Mouths of Nurses: “The Tale of Sagoromo" And Midranks Romance'.

70 Ibid., p. 153.

71 Tyler, The Disaster of the Third Princess, p. 16.
} 
conceives. The Third Princess, in her guilt and also fading away from illness (also caused by Rokujōs ghost) begs her father, Suzaku, to make her a nun. Suzaku, meanwhile, realises the extent to which Genji has wronged his daughter, and later comes back as a ghost to wreak havoc on Genji's son. ${ }^{72}$

The significance of this episode is its complete denial of the (male) fantasy of monogamy. In Murasaki, Genji has a perfect wife, whom he has reared to his own exacting standards of taste. It is especially after his marriage to the Third Princess (whom he finds 'too dismally dull') ) $^{73}$ that Genji appreciates Murasaki, but by then he is inexorably bound in his duties to the Third Princess. When he neglects the Third Princess, as he really cannot afford to do, despite being the most powerful commoner in the land, it all ends (to borrow the title of Tyler's collection of essays) in disaster. ${ }^{74}$

\section{Conclusion}

In this thesis, I have examined the construction of two models of male sexuality in Heian literature, that of the irogonomi and that of the pseudo-monogamous lover-husband. Both initially introduced in male-authored literature, Murasaki Shikibu later took up the two models, preserving the fundamental characteristics but altering the finer details in ways that subtly challenged the gendered hierarchies inherent to both models. I have argued that both the irogonomi and monogamous lover-husband tropes began, at least partially, as reactions against women's influence in the real world. The irogonomi was a reaction against loveless political marriage, and I have argued that the monogamous husband likewise arose as a literary attempt to write women's central role in marriage politics out of the picture. However, when Murasaki Shikibu took up these two models, she depicted the ill-consequences of men's sexual prerogatives in an indirect indictment and a refusal of the fantasies of easy promiscuity as represented by the irogonomi or of deliberate and cultured monogamy. Genji is popularly remembered as a model Heian courtier. However, in light of my research, I would argue that Genji is more accurately the sum of the rejection of two fantasies of male sexuality. 
New Voices Volume 5

\section{References}

Arntzen, S. (trans.), The Kagerō Diary (Ann Arbor: University of Michigan, 1997).

Bowring, R., 'The Ise Monogatari: A Short Cultural History', Harvard Journal of Asiatic Studies, vol. 52, no. 2 (1992), pp. 401-80.

Childs, M. H., 'The Value of Vulnerability: Sexual Coercion and the Nature of Love in Japanese Court Literature', The Journal of Asian Studies, vol. 58, no. 4 (1999), pp. 1059-79.

D'Etcheverry, C. B., 'Out of the Mouths of Nurses: “The Tale of Sagoromo” And Midranks Romance', Monumenta Nipponica, vol. 59, no. 2 (2004), pp. 153-77.

Fukutō, S. and Watanabe, T., 'From Female Sovereign to Mother of the Nation: Women and Government in the Heian Period,' in Adolphson, M., Kamens, E., and Matsumoto, S. (eds.), Heian Japan: Centers and Peripheries (Honolulu: University of Hawai'i Press, 2007), pp. 15-34.

Keene, D., Seeds in the Heart: Japanese Literature from Earliest Times to the Late Sixteenth Century (New York: Henry Holt \& Co., 1993).

McCullough, H. C., Tales of Ise: Lyrical Episodes from Tenth-Century Japan (Tokyo: University of Tokyo Press, 1978).

McCullough, H. C., Okagami, the Great Mirror: Fujiwara Michinaga (966-1027) and His Times (Ann Arbor: Center for Japanese Studies, University of Michigan, 1991).

McCullough, W. H., 'Japanese Marriage Institutions in the Heian Period', Harvard Journal of Asiatic Studies, vol. 27 (1967), pp. 103-67.

McCullough, W. H., 'The Heian Court, 794-1070', in Shively, D. H. and McCullough, W. H. (eds.), Heian Japan (Cambridge: Cambridge University Press, 1999), pp. 20-96.

McCullough, W. H. and McCullough, H. C., A Tale of Flowering Fortunes: Annals of Japanese Aristocratic Life in the Heian Period (Stanford, California: Stanford University Press, 1980), 2 vols.

Mostow, J., 'The Amorous Statesman and the Poetess: The Politics of Autobiography and the Kagerō Nikki', Japan Forum, vol. 4, no. 2 (1992), pp. 305-15.

Mostow, J. and Tyler, R., The Ise Stories: Ise Monogatari (Honolulu: University of Hawai'i Press, 2010).

Nakamura, S., Irogonomi No Kōzō: Ōchō Bunka No Shinsō (Tokyo: Iwanami Shoten, 1985).

Nickerson, P., 'The Meaning of Matrilocality: Kinship, Property, and Politics in Mid-Heian', Monumenta Nipponica, vol. 48, no. 4 (1993), pp. 429-67.

Okada, H. R., Figures of Resistance: Language, Poetry, and Narrating in the Tale of Genji and Other Mid-Heian Texts (Durham: Duke University Press, 1991).

Schalow, P. G., 'Five Portraits of Male Friendship in the Ise Monogatari', Harvard Journal of Asiatic Studies, vol. 60, no. 2 (2000), pp. 445-88.

Shirane, H., 'The Uji Chapters and the Denial of the Romance', in Pekarik, A. (ed.), Ukifune: Love in the Tale of Genji (New York: Colombia University Press, 1982), pp. 113-38.

Shirane, H., The Bridge of Dreams: A Poetics of 'the Tale of Genji' (Stanford: Stanford University Press, 1987). 
Tonomura, H., 'Women and Inheritance in Japan's Early Warrior Society', Comparative Studies in Society and History, vol. 32 , no. 3 (1990), pp. 592-623.

Tyler, R., The Disaster of the Third Princess (Canberra: ANU E Press, 1999).

Tyler, R. (trans.), The Tale of Genji (New York, London: Viking, 2001).

Tyler, R., 'Marriage, Rank and Rape in the Tale of Genji', Intersections, vol. 7 (2002).

Wakita, H. and Gay, S., 'Marriage and Property in Premodern Japan from the Perspective of Women's History', Journal of Japanese Studies, vol. 10, no. 1 (1984), pp. 73-99.

Whitehouse, W. and Yanagisawa, E. (trans.), The Tale of the Lady Ochikubo: Ochikubo Monogatari (London: Kegan Paul, 2006). 